Ann. Biol. anim. Bioch. Biophys., 1978, 18 (4), 837-842.

\title{
Hypothalamic centers and innervation of the hypophysis in the Atlantic salmon (Salmo salar) and the rainbow trout (Salmo gairdneri)
}

\author{
par B. EKENGREN, M. TERLOU * \\ University of Stockholm, Deportment of Zoology, Box 6801, 11386 Stockholm, Sweden \\ * Zoological laboratory, Section Comparative Endocrinology, Padualaan 8, \\ Utrecht, The Netherlands.
}

\begin{abstract}
Summary. The nucleus preopticus (NPO), the nucleus lateralis tuberis (NLT) and the paraventricular organ (PVO), presumed to produce adenohypophysiotropic factors and to be involved in reproductive processes, have been studied in two salmonids. The cell bodies and especially their axonal contacts with the hypophysis were thoroughly examined.

The Falck-Hillarp method revealed a high amount of aminergic fibers in all parts of the neurohypophysis. There were only small differences between different areas and between the two species. The fibers may originate in the PVO. The pseudoisocyanin method showed that all paris of the neurohypophysis had NPO-terminations, most abundant in the neuro-intermediate lobe. Fluorescing, possibly aminergic, cells were found in the trout hypophysis. The NPO had a high input of aminergic fibers, possibly originating in the PVO. Cells of the medial part of the NLT received many aminergic fibers ; NPO-fibers also passed very close to these cells. This pattern implied a rich double innervation of the NLT cells. The results lead to the suggestion of a functional relationship among the three hypothalamic nuclei.
\end{abstract}

\section{Introduction.}

In the hypothalamus of teleost fishes three nuclei have received special attention. They are the nucleus preopticus (NPO), the nucleus lateralis fuberis (NLT), and the complex of the nucleus recessus lateralis (NRL) and posterioris (NRP) comprising the paraventricular organ (PVO) of teleosts (NPO : Holmes and Ball, 1974 ; Simon and Reinboth, 1974 ; NLT : Ekengren, 1973 ; PVO : Ekengren, 1975b). These nuclei have received attention because they have been suggested to influence the hypophysis by nerve fibers innervating the hypophysis (Simon and Reinboth, 1974 ; Holmes and Ball, 1974 ; Baumgarten and Braak, 1967 ; Fremberg and Meurling, 1975). Contacts among the three nuclei have also been reported (Baumgarten and Braak, 1967 ; Weiss, 1970, 1976 ; Ekengren, 1973, 1975b). The present study deals with the distribution of cells of the NPO, NLT and PVO (NRL/NRP) and especially their relation to the hypophysis and to each other. 


\section{Materials and methods.}

Animals. - Rainbow trout (Salmo gairdneri) and salmon (Salmo salar) 1-3 years old, most of them sexually mature, were supplied from hatcheries in Vaasen, Holland and Älvkarleby, Sweden, respectively. They were kept in aquaria some days before being killed.

Histological techniques. - The brains of 14 trout and 12 salmon were excised and fixed in Bouin-Hollande. After embedding, transverse and sagittal 5-7 $\mu \mathrm{m}$ sections were cut. They were stained with Gomori's chromalum-haematoxylin-phloxin, Bock's p-rosanilin-crotonaldehyde, N-N'-diethylpseudoisocyanin chloride or Herlant's tetrachrome.

12 trout and 10 salmon were used for the Falck-Hillarp technique. Some fishes of both species received an injection of nialamide intraperitoneally $(25-100 \mathrm{mg} / \mathrm{kg}) 3 \mathrm{hrs}$ before killing. The brains, with hypophyses attached, were excised, frozen in liquid propane and freeze-dried in a Pearse or a coldfinger freezedryer. The material was then treated with gaseous paraformaldehyde for 1-3 hrs, embedded in paraffin and cut into transverse, sagittal and horizontal sections of 5-7 $\mu \mathrm{m}$. These were examined in a Zeiss fluorescence microscope.

\section{Results.}

Hypothalamic nuclei. - The localization and structure of the NPO in the two salmonids is similar to that described for other teleosts; i.e. a pars parvocellularis and a pars magnocellularis with small and large cells, respectively, many of them liquorcontacting.

The NLT starts at the level of the horizontal commissure and extends caudally to the lateral recesses. The most prominent part is the pars lateralis with many rows of large cells. In the salmon the pars medialis is much more extensive than in the trout.

FIG. 1. $-F-H+$ fibers in the rostral neurohypophysis $(\pi \mathrm{RNH})$. Note some fluorescent cells. $\times 375$.

FIG. 2. $-F-H+$ beaded axons and terminations in the RNH, Prolactin follicle (P.). $\times 375$.

FIG. 3. $-F-H+$ fibers in the neuro-intermediate lobe (NIL), with a concentration of the neuro-adeno interface $(\swarrow), \times 240$.

FIG. 4. - PIC + fibers in the RNH. $\times 200$.

FIG. 5. $-F-H+$ fibers in the NIL. $\times 375$.

FIG. 6. $-P I C+$ fibers in the NIL. $\times 375$.

FIG. 7. $-F-H+$ fibers running through the NLT. $\times 150$.

FIG. 8. - PIC + fibers from the NPO passing throogh the NLT $(\swarrow) \times 150$.

FIG. 1-3,5,7: ...... Falck-Hillarp reaction (F-H) ; FIG. 4,6,8 : ...... Pseudoïsocyanin reaction $(\mathrm{PIC})$.

FIG. 1 is from trout and the others are from salmon. 


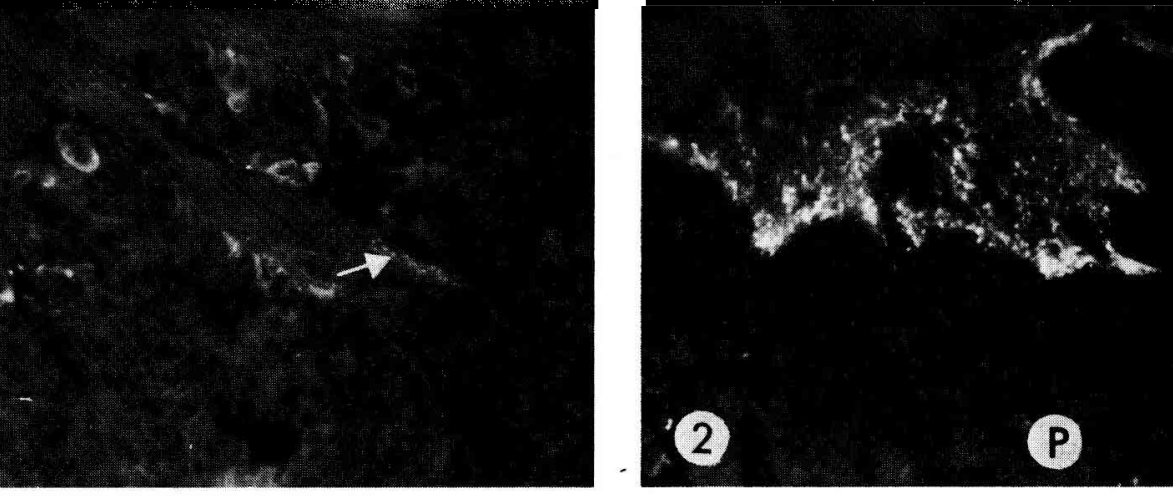

(1)
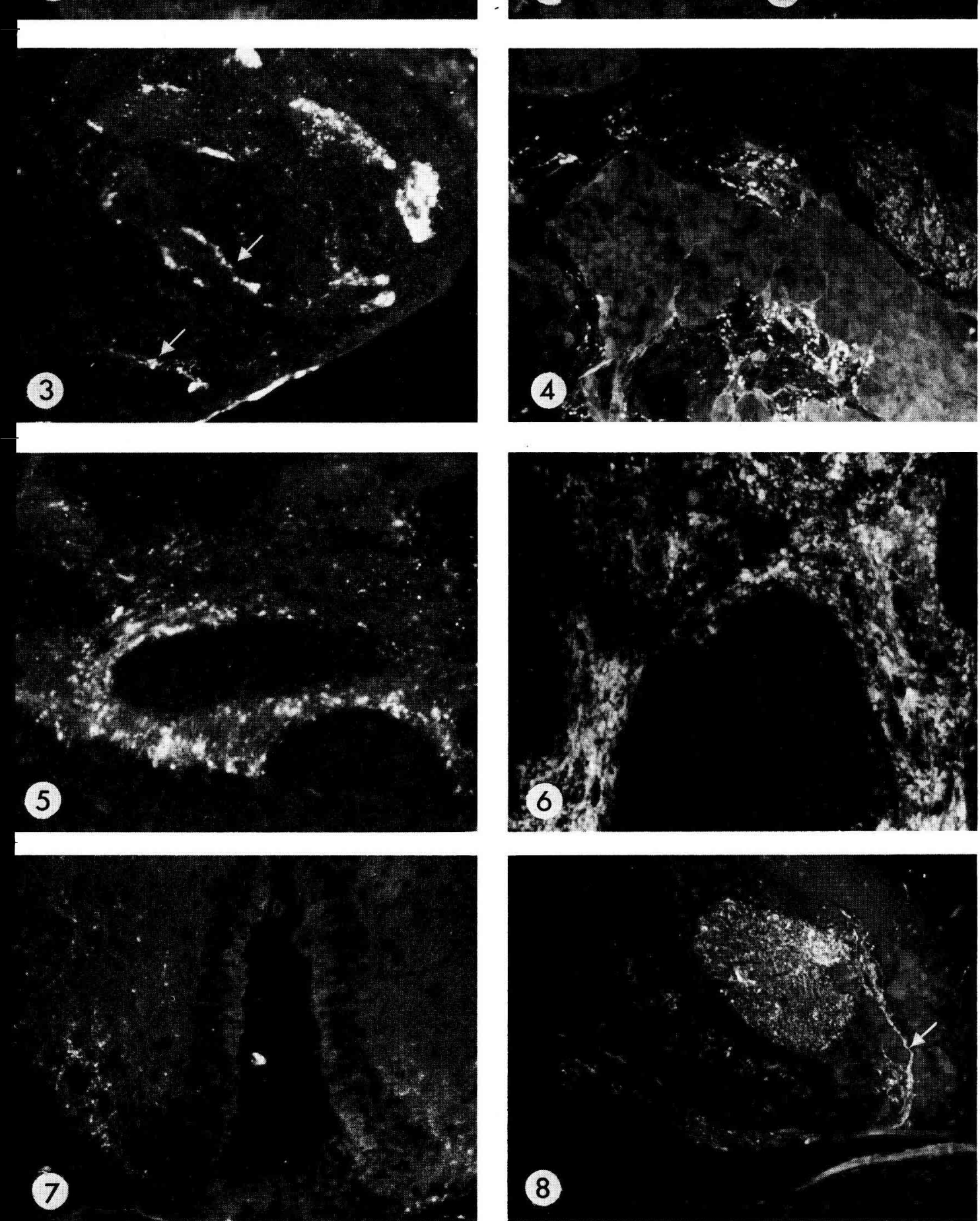
The Falck-Hillarp technique revealed fluorescent cells on both sides of the ventricular system comprising the complex of the NRL and NRP. The localization is in agreement with that described for other teleosts.

Innervation of hypophysis. - After treatment according to the Falck-Hillarp method, fluorescent fibers were seen in all parts of the neurohypophysis (fig. 1, 2, 3, 5). The distribution was the same for both species, but the intensity was much lower in the trout (fig. 1). Fluorescent cells (fig. 1) were only found in the trout. Pseudoisocyaninpositive (PIC + ) fibers were found in both the rostral neurohypophysis (fig. 4) and in the neuro-intermediate lobes (NIL) (fig. 6). The distribution of a minergic and PIC + fibers in the NIL are strikingly similar (fig. 5,6 ).

Innervation of hypothalamic nuclei. - The NPO was found to have a high input of fluorescent fibers after the Falck-Hillarp reaction. They very probably originate in the NRL/NRP. PIC + fibers from the NPO pass between and close to the cells of the NLT pars lateralis (fig. 8) and contacts were indicated. A few Falck-Hillarp-positive fibers rostrally also invade this part of the NLT (fig. 7), but most fibers are close to cells of the medial part of the nucleus.

\section{Discussion.}

The general composition of the NPO coincides well with descriptions of other teleosts (Holmes and Ball, 1974 ; Simon and Reinboth, 1974). This is also true of the NLT (Ekrengren, 1973), except that the medial part is more extensive in the salmon. The general outline of the PVO is also in agreement with other descriptions (Ekengren, 1975b).

As in most species the majority of the NPO fibers terminate in the neuro-intermediate lobe (Simon and Reinboth, 1974), but as in a few species some fibers end in the rostral neurohypophysis (Båge et al., 1974a, b). The entire neurohypophysis receives a strong aminergic innervation, which has been described for a few species (Ekengren, 1975a ; Fremberg and Meurling, 1975). Fluorescent cells were only present in the trout hypophysis, a feature described for just a few species (Weiss, 1970 ; Bàge ef al., 1974b). It is for the moment uncertain which cell type is reacting, but more work is planned.

The presence of aminergic fibers in close contact with NPO cells points to an aminergic innervation of the nucleus. This is in accordance with results from other teleost fishes (Baumgarten and Braak, 1967 ; Weiss, 1970 ; Ekengren, 1973). To trace the origin of these fibers lesion experiments will be carried out.

An interesting result of this study was the high amount of both NPO and aminergic fibers passing between the cells of the NLT complex. A similar pattern has been described for the brook trout (Salmo trutta fario) by Weiss (1976), and for the roach (Leuciscus rutilus) (Ekengren, 1973). These findings must be considered when lesions are made in this area.

The contact among the three hypothalamic nuclei as well as their contact with the hypophysis suggests interesting functional interactions. 


\section{Conclusions.}

All parts of the neurohypophysis have a more or less rich innervation from the NPO, and some aminergic nucleus, possibly the PVO. Aminergic cells are possibly present in the pituitary of trout. The NPO receives many aminergic fibers, very probably from the PVO. The NLT has a high input of NPO and aminergic fibers, the latter possibly originating in the PVO. All these contacts indicate a functional relafionship among the three hypothalamic nuclei and also with the hypophysis.

\section{Symposium sur la Reproduction des Poissons Paimpont, France, 19-21 septembre 1977.}

Acknowledgment. - Dr. M. Terlou gratefully acknowledges the financial support of the Netherlands Crganization for the Advancement of Pure Research (ZWO). Dr. B. Ekengren gratefully acknowledges the financial support of the Swedish Natural Science Research Council.

Résumé. Les noyaux pré-optiques (NPO), latéral du tuber (NLT), ef l'organe paraventriculaire (PVO), supposés responsables de la production des facteurs adénohypophysiotropes et concernés dans la fonction de reproduction, ont été étudiés chez 2 salmonidés. Nous nous sommes intéressés aux corps cellulaires des neurones et particulièrement à leurs contacts axonaux avec l'hypophyse.

La technique de Falck et Hillarp permet la mise en évidence d'une grande quantité de fibres aminergiques dans toute la neurohypophyse. Seules de petites différences entre les différentes parties de la neurohypophyse et entre les 2 espèces ont pu être notées. Ces fibres semblent prendre naissance dans l'organe paraventriculaire. La technique à la pseudoisocyanine permet de montrer qu'il existe à tous les niveaux de la neurohypophyse des terminaisons de fibres issues du noyau NPO, la plus grande densité s'observant au niveau du lobe nerveux-intermédiaire. Des cellules fluorescentes pouvant être aminergiques ont été trouvées chez la truite. Le NPO reçoit un grand nombre de fibres aminergiques pouvant provenir de PVO. Les cellules de la partie médiane du NLT reçoivent de nombreuses fibres aminergiques; de plus des fibres originaires du NPO passent très près de ces cellules. Cela indique l'existence d'une riche double innervation des cellules du NLT. Ces résultais suggèrent donc une relation fonctionnelle entre les 3 noyaux hypothalamiques, et également à l'hypophyse.

\section{References}

BAGE G., EKENGREN B., FERNHOLM B., FRIDBERG G., 1974a. The pituitary gland of the roach Leuciscus ruticulus. I. The rostral pars distalis and its innervation. Acto zool. (Stockh.), 55, 25-45.

BAGE G., EKENGREN B., FERNHOLM B., FRIDBERG G., 1974b. The pituitary gland of the roach Leuciscus rutilus. II. The proximal pars distalis and its innervation. Acta zool. (Stockh.), 55, 191-204.

BAUMGARTEN H. G., BRAAK H., 1967. Catecholamine im Hypothalamus vom Goldfisch (Carassius ouratus). Z. Zellforsch., 80, 246-263.

EKENGREN B., 1973. The nucleus preopticus and the nucleus lateralis tuberis in the roach, Leuciscus rutilus. Z. Zellforsch., 140, 369-388.

EKENGREN B., 1975a. The aminergic innervation of the pituitary gland in the roach Leuciscus rutilus. Cell Tiss. Res., 158, 169-175. 
EKENGREN B., 1975b. Aminergic nuclei in the hypothalamus of the roach Leucicus rutilus. Cell Tiss. Res., 159, 493-502.

FREMBERG M., MEURLING P., 1975. Catecholamine fluorescence in the pituitary of the eel, Anguillo anguilla, with special reference to its variation during background adaptation. Cell Tiss. Res., 157, 53-72.

HOLMES R. L., BALL J. N., 1974. The pituitary gland. A comparative occount. Cambridge Univ. Press, London.

SIMON N., REINBOTH R., 1974. Adenohypophyse und Hypothalamus : histophysiologische Untersuchungen bei Lepomis (Centrarchidae). Adv. Anat., Embr., Cell Biol., 48, Fasc. 6, 1-82.

WEISS J., 1970. Saisonale Veränderungen des Enzymmusters und des neurosekretgehaltes sowie die Innervation des Nucleus praeopticus der Bachforelle (Salmo trufta fario) unter besonderer Berücksichtigung der hypothalamischen Hydrencephalokrinie. Morph. Jb., 115, 444-486.

WEISS J., 1976. Untersuchungen zur Innervation des Nucleus lateralis tuberis der Bachforelle (Salmo trutfa fario). Biol. Zbl., 96, 43-56. 